\title{
Pengaruh Dana Pihak Ketiga, Capital Adequacy Ratio, Non Performing Loan Dan Tingkat Suku Bunga terhadap Penyaluran Kredit Bank Umum Yang Terdaftar di Bursa Efek Indonesia
}

\author{
Venna Melinda, Velicia, Kenji Lau, Rafida Khairani* \\ Universitas Prima Indonesia, Medan \\ ${ }^{*}$ Correspondence email: rafidakhairani256@gmail.com
}

\begin{abstract}
Abstrak. Ekonomi berkembang di saat ini mendorong perbankan fokus untuk menghimpun dana serta menyalurka kreditnya kepada masyarakat yang memerlukannya guna memenuhi kebutuhannya. Dana dihimpunnya dikenal DPK. Tujuan penelitiannya ini ialah menguji dan menganalisis pengaruh Dana Pihak Ketiga, Capital Adequacy Ratio, Non Performing Loan serta Tingkat Suku Bunga secara stimulant dan parsial pada Penyaluran Kredit Bank Umum yang tercantum di BEI. Jenis Penelitian yang dipergunakan yaitu Kuantitatif. Bersifat kausal penelitiannya dan datanya kuantitatif dengan skalanya rasio. Data dikumpulkannya dokumentasi dan data sekunder. Populasinya keseluruhan bank umum yang tercantum di BEI tahun $2014-$ 2018 yaitu 45 Bank. Sampel penelitian berjumlah 22 perusahaan. Penelitian ini dianalisis dengan regresis linear berganda. Hasilnya Dana Pihak Ketiga, Non Performing Loan, Capital Adequacy Ratio, serta Tingkat Suku Bunga secara parsial dan stimulan mempunyai pengaruh pada Penyaluran Kredit Bank Umum yang tercantum di BEI.
\end{abstract}

Kata Kunci: Capital Adequacy Ratio; Dana Pihak Ketiga; Non Performing Loan; Tingkat Suku Bunga dan Penyaluran Kredit

Abstract. Today's developing economy encourages banks to focus on raising funds and channeling credit to people who need them to meet their needs. The funds he raises are known as DPK. The purpose of this research is to examine and analyze the effect of Third Party Funds, Capital Adequacy Ratio, Non-Performing Loans and Interest Rate Stimulant and Partial on Commercial Bank Credit Distribution listed on the IDX. This type of research used is quantitative. The research is causal and the data is quantitative with a ratio scale. Data collected documentation and secondary data. The total population of commercial banks listed on the IDX in 2014 - 2018 in 45 banks. The research sample consisted of 22 companies. This study was analyzed by multiple linear regression. The result is that Third Party Funds, Non-Performing Loans, Capital Adequacy Ratio, and Partial and stimulant Interest Rates have an influence on Commercial Bank Credit Distribution listed on the IDX.

Keywords: Capital Adequacy Ratio; Interest Rates; Non-Performing Loans; Third-Party Funds, and Lending

\section{PENDAHULUAN}

Perekonomian yang berkembang pesat ini mendorong perbankan untuk menyalurkan kredit dari dana yang dihimpunnya. Dana terhimpun perbankan bentuknya simpanannya giro, deposito dan tabungan sehingga perbankan dapat menjalankan kegiatan usahanya dan biasanya dikenal dengan dana pihak ketiga. Dana bank terbesar sumbernya ialah dana yang dihimpun masyarakat disebutDana Pihak Ketiga (DPK) mencakup dana yang sumbernya dari masyarakat berbentuk Dana Pihak Ketiga memberikan pengaruhnya pada kredit masyarakat. Penghimpunan dana ini tinggi maka kredit yang disalurkan tinggi. Capital Adequacy Ratio (CAR) dikenal dengan permodalan biasanya sebagai modal dasar yang dipenuhi pihak perbankan. Permodalan ini untuk mengatasi risiko jika dana yang dikumpulkan tinggi. Capital Adequacy Ratio tinggi digunakan dalam pengembangan usahanya dan mencegah terjadinya kerugian akibat dari saluran kredit banknya. Dalam dunia perbankan, Non perfoming Loan merupakan risiko kredit yang paling mendasar, kegagalan bank dalam mengelola risiko kredit dapat menimbulkan risiko bank lainnya. Semakin tinggi tingkat Non perfoming Loan menunjukkan tingkat risiko penyaluran kredit yang bakal terjadi di bank juga cukup tinggi. Non perfoming Loan tinggi dapat mengurangi kredit yang disalurkan pada masyarakatnya. Suku bunga tiap waktu berubah-ubah sehingga berdampak pada pendapatan bunga yang terjadi di perusahaan. Nasabah lebih senang pada suku bunga yang tinggi daripada suku bunga rendah. Penurunan pendapatan bunga pinjaman mengakibatkan kredit bermasalahnya meningkat. Kredit yang disalurkan berkurang dari sebelumnya guna penghindaran kredit macet tinggi diakibatkan nasabah melakukan pembayaran yang tidak tepat waktu. Kredit macet yang terjadi pada tahun 2016 di Bank Negara Indonesia (Persero) Tbk yaitu berjumlah $\mathrm{Rp}$ 9.211.661.000.000,- mengalami peningkatan dengan kredit yang diberikan pada tahun 2016 yakni berjumlah Rp 393.275.392.000.000,- meningkat. Kredit macet meningkat seharusnya membuat pihak bank lebih ketat dalam meluncurkan kredit. Sehingga tentunya ketika kredit macet meningkat akan otomatis memperketat kredit yg diberikan. Bank Sinar Mas Tbk memiliki dana pihak ketiga di tahun 2018 berjumlah $\mathrm{Rp}$ 21.989.429.000.000,- menurun dengan kredit yang diberikan pada tahun 2018 berjumlah $\mathrm{Rp}$ 19.844.642.000.000,- meningkat. Dana pihak ketiga 
Venna Melinda, Velicia, Kenji Lau dan Rafida Khairani, Pengaruh Dana Pihak Ketiga, Capital Adequacy Ratio, Non Performing Loan Dan Tingkat Suku Bunga terhadap Penyaluran Kredit Bank Umum Yang Terdaftar di Bursa Efek Indonesia

menurun seharusnya dapat menurunkan kredit yang diberikan namun kenyataan dana pihak ketiga menurun tetapi kredit diberikan meningkat. Modal di tahun 2017 berjumlah Rp 4.549.755.000.000,- meningkat dengan jumlah kredit diberikan tahun 2017 sebesar $\mathrm{Rp}$ 18.759.953.000.000,- menurun. Modal meningkat seharusnya meningkatkan jumlah kredit diberikan namun modal meningkat justru menurunkan jumlah kredit yang diberikan. Suku bunga Bank Maspion Indonesia Tbk yang terjadi di tahun 2018 sebesar 6\% meningkat dengan jumlah kredit yang diberikan pada tahun 2018 sebesar Rp 4.976.591.404.000,meningkat. Suku bunga yang meningkat seharusnya menurunkan jumlah kredit yang diberikan namun kenyataannya suku bunga yang mengalami peningkatan dapat mengakibatkan jumlah kredit yang diberikan juga meningkat. Adapun diidentifikasi masalah penelitiannya yakni: peningkatan maupun penurunan Dana Pihak Ketiga, Capital Adequacy Ratio, Tingkat Suku Bunga, serta Non Performing Loan, tidak diikuti dengan peningkatan maupun penurunan Penyaluran Kredit Bank Umum yang tercantum di BEI.

Menurut Adnan, Ridwan dan Fildzah (2016) dana pihak ketiga yang didapat bank dari dana masyarakat yang simpan dibank dalam bentuk deposito, tabungan, dan giro. Oleh bank, dana masyarakat ini disalurkan kembali kepada masyarakat yang membutuhkan dana dalam bentuk kredit.

Menurut Putri dan Akmalia (2016) Apabila capital adequacy ratio suatu bank mengalami kekurangan dalam memenuhi modalnya maka hal itu akan dapat menghambat bank dalam menyalurkan kredit kepada masyarakat. Semakin tinggi nilai capital adequacy ratio maka bank dapat menyalurkan kreditnya.

Menurut Pratiwi dan Hindasah (2014) menyebutkan Semakin besarnya kredit macet maka semakin meningkat pula nilai NPL bank dan kredit yang disalurkan semakin sedikit karena Bank tidak mempunyai dana untuk menyalurkannya kembali akibat kredit macet dan Bank juga enggan menyalurkan kreditnya karena mempunyai resiko tinggi terhadap hutang tak tertagih.

Menurut Sari dan Abundanti (2016) kegiatan dalam manajemen perbankan dalam meminimalkan risiko kredit macet ialah mencari alternatif investasi yang lebih baik yaitu salah satunya melakukan penempatan dana pada SBI yang memiliki tingkat risiko paling rendah. Oleh karena itu, jika jumlah dana yang ditempatkan pada SBI meningkat maka penyaluran kredit perbankan dapat berkurang.

Berdasarkan pendapat di atas disimpulkan tingginya suku bunga mengakibatkan penurunan kredit yang disalurkan kemudian rendahnya suku bunga maka kredit yang disalurkan tinggi

\section{METODE}

Bank umum yang tercantum di BEI menjadi tempat penelitian serta diakses dengan www.google.com dan www.idx.co.id. Bulan November 2019 mulai penelitian ini Kuantitatif pendekatannya dengan metode statistik. Dokumentasi sebagai cara pengumpulan datanya. Data sekunder yang dilakukan penelitian ini dengan memperoleh data keuangan Bank umum tercatat di BEI tahun 2014-2018 sebanyak 45 bank. Sampelnya ditarik secara purposive sampling method dengan kriteria tertentu.Persyaratan purposive sampling yakni:

1. Bank Umum yang tercatat di BEI Tahun 20142018.

2. Bank Umum yang mempublikasi laporan keuangannya Tahun 2014-2018

3. Bank Umum yang memperoleh laba secara berturutturut dari periode Periode 2014- 2018.

Sampelnya sebanyak 27 Bank umum dengan jumlah pengamatan sebanyak 5 tahun sehingga sampel 135 data

Tabel 1. Definisi Operasional Variabel

\begin{tabular}{|c|c|c|c|}
\hline No & Variabel & Definisi Variabel & Skala \\
\hline 1 & Dana Pihak Ketiga $\left(\mathrm{X}_{1}\right)$ & $\begin{array}{l}\text { Dana pihak ketiga ialah dana dari masyarakat secara perorangan,badan } \\
\text { usaha diperoleh dari produk simpanan yang dimiliki bank. Baskoro dan } \\
\text { Moeliono }(2014: 805)\end{array}$ & Rasio \\
\hline 2 & Capital Adequacy Ratio $\left(\mathrm{X}_{2}\right)$ & $\begin{array}{l}\text { CAR yaitu perbandingan antara modal dan aktiva tertimbang berdasarkan } \\
\text { resiko ATMR (Aktiva Tertimbang Menurut Risiko). Darmawi (2014:97) }\end{array}$ & Rasio \\
\hline 3 & Non Performing Loan $\left(\mathrm{X}_{3}\right)$ & $\begin{array}{l}\text { Non Performing Loan (NPL) ialah ketidakmampuan nasabah dalam } \\
\text { melunasi pinjamannya. } \\
\text { Latumaerissa (2014:164) }\end{array}$ & Rasio \\
\hline 4 & Suku Bunga $\left(\mathrm{X}_{4}\right)$ & $\begin{array}{l}\text { Suku bunga yaitu harga yang dibayarkan atas penggunaan kredit. } \\
\text { Latumaerissa }(2014: 183)\end{array}$ & Rasio \\
\hline 5 & Penyaluran Kredit (Y) & $\begin{array}{l}\text { Penyaluran Kredit ialah penyediaan uang oleh bank untuk disalurkan } \\
\text { kepada nasabah dan nasabah wajib melunasi utangnya. } \\
\text { Undang-Undang yang tertera dalam pasal } 1 \text { ayat } 11 \text { UU No.10/1998 }\end{array}$ & Rasio \\
\hline
\end{tabular}

\section{Teknik Analisis Data}

Analisis datanya regresi linear berganda, asumsi klasik diikuti dengan hipotesis pengujiannya.

\section{Uji Normalitas}


Venna Melinda, Velicia, Kenji Lau dan Rafida Khairani, Pengaruh Dana Pihak Ketiga, Capital Adequacy Ratio, Non Performing Loan Dan Tingkat Suku Bunga terhadap Penyaluran Kredit Bank Umum Yang Terdaftar di Bursa Efek Indonesia

Normalitas pengujiannya dilakukan dengan grafik dan statistik. Grafiknya histogram berbentuk lonceng terbalik dan normal p-plot mendekati garis diagonal berarti normal. Statistik dengan kolmogorov-smirnov yang signifikan diatas 0,05 .

\section{Uji Multikolinieritas}

Multikolinieritas pengujiannya membuktikan adanya korelasi atau tidak dengan kriteria Tollerance diatas 0,1 serta VIF dibawah sepuluh.

\section{Uji Autokorelasi}

Autokorelasi pengujiannya membuktikan ada tidaknya variabel kesalahan penggangu dan biasanya diukur dengan tabel statistik durbin Watson

\section{Uji Heteroskedastisitas}

Dari hasil Uji heteroskedastisitas terlihat Datanya bersifat heterogen untuk pengujian heteroskedastisitas, data yang sifat pergerakannya sama dengan kriteria secara acak penyebarannya membuktikan data bebas dari permasalahan heterokedastisitas. Pengujian heterokedastisitas dapat dilakukan secara grafik scatterplot dengan kriteria menyebar secara acak dan statistiknya dengan uji glejser berkriteria signifikan > 0,05 memperlihatkan tidak terdapat heterokedastisitas. Asumsi klasik pengujiannya terpenuhi maka data penelitian ini memenuhi syarat dapat digunakan selanjutnya pengujian hipotesisnya dilakukan penelitian ini.

\section{Analisis Regresi Linier Berganda}

Analisis ini dilakukan dengan rumusan:

$Y=a+b_{1} X_{1}+b_{2} X_{2}+b_{3} X_{3}+b_{4} X_{4}+e$

\section{Keterangan :}

Y : Penyaluran Kredit

a : konstanta

$\mathrm{X}_{1} \quad$ : Dana Pihak Ketiga

$\mathrm{X}_{2} \quad$ : Capital Adequacy Ratio

$\mathrm{X}_{3} \quad$ : Non Performing Loan

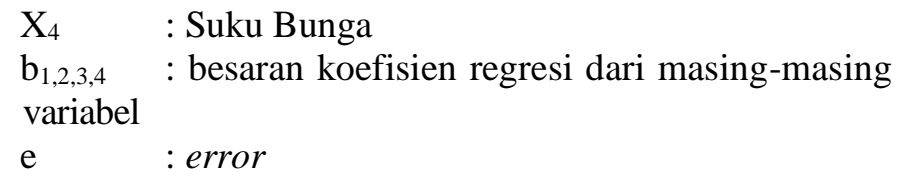

Hipotesis pengujiannya dimulai dari uji parsial, uji simultan serta koefisien determinasi $\left(\mathrm{R}^{2}\right)$.

\section{Pengujian secara parsial (uji t)}

Uji ini memiliki tujuan guna memberikan pengaruh per satu variabel independent pada variabel dependent dengan kriteria pengujian t ini signifikansinya $>0,05$ maka variabel independent berperngaruh terhadap variabel dependennya

\section{Pengujian secara simultan (uji F)}

Uji ini memeliki tujuan guna memahami apakah variabel independent yang di pergunakan secara bersama-sama memliki pengaruh signifikan pada variabel dependennya atau tidak kriteria pengujian $F$ dengan signifikan di bawah 0.05 berpengaruh.

\section{Koefisien Determinasi $\left(\mathbf{R}^{2}\right)$}

Uji ini memiliki tujuan guna memahami seberapa kuatnya kemampuan variabel independent dalam mempengaruhi serta menjelaskann variabel dependennya. Biasanya koefisien determinasi yang baik mendekati nilai 1 menunjukkan pengaruhnya sangat kuat dalam pengujiannya.

\section{HASIL DAN PEMBAHASAN}

Statistisk deskriptif dilaksanakan pertama kali dalam mengolah data untuk mengetahui jumlah data, nilai rendah, tinggi, rata-rata dan standar deviasi kemudian asumsi klasik serta hipotesis.

\section{Data Deskriptif}

Sampel yang dipergunakan berjumlah 27 Bank Umum yang tercatat di BEI sehingga total sampel yang dipergunakan yaitu 135 sampel. Deskripsinya diuji yaitu :

Tabel 2. Deskriptif Statistik

Descriptive Statistics

\begin{tabular}{lr|r|r|r|r} 
& $\mathrm{N}$ & \multicolumn{1}{c}{ Minimum } & Maximum & \multicolumn{1}{c}{ Mean } & Std. Deviation \\
\hline DPK & 135 & 61.12 & 97.83 & 83.4557 & 5.60112 \\
\hline CAR & 135 & 10.25 & 66.43 & 20.6293 & 6.70689 \\
\hline NPL & 135 & .07 & 4.87 & 1.7407 & 1.09162 \\
\hline BIRATE & 135 & 60.00 & 375.00 & 362.0000 & 269.65650 \\
\hline PenyaluranKredit & 135 & 28.12 & & 31.4576 & 1.58964 \\
\hline Valid N (listwise) & 135 & & & & \\
\hline
\end{tabular}

Sumber: diolah data 
Venna Melinda, Velicia, Kenji Lau dan Rafida Khairani, Pengaruh Dana Pihak Ketiga, Capital Adequacy Ratio, Non Performing Loan Dan Tingkat Suku Bunga terhadap Penyaluran Kredit Bank Umum Yang Terdaftar di Bursa Efek Indonesia

2. Sampelnya 135 untuk Capital Adequacy Ratio, nilai terendah 10,25, max 66,43, mean 20.6293 dan std deviasi 6.70689.

3. Sampelnya 135 untuk Non Performing Loan, nilai terendah 0,07 , max 4,87, mean 1,7407 dan std deviasi 1.09162 .

4. Sampelnya 135 untuk Tingkat Suku Bunga, nilai terendah 60,00, max 775,00, mean 362.0000 dan std deviasi 269.65650.

5. Sampelnya 135 untuk Penyaluran Kredit, nilai terendah 28,12, max 34,48, mean 31.4576 dan std deviasi 1.58964.

\section{Asumsi Klasik}

\section{Normalitas}

Normalitas ada dua: grafik dan statistik. Grafik normalitas terlihat normal berbentuk parabola terbalik. Histogram ini disajikan:

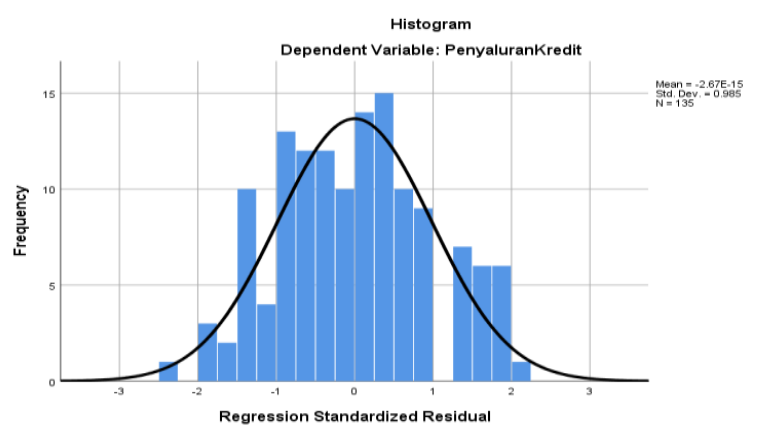

Gambar 1. Histogram

Grafik histogram memperlihatkan tiak miring kekanan maupun kiri, membentuk sebuah parabola terbalik jadi data normal. berikut:

Grafik normal p-p-plot dapat diperlihatkan

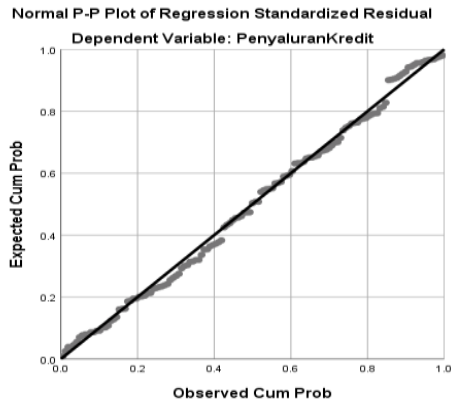

Gambar 2. Normal p-p-Plot
Grafik normal p-p-plot memperlihatkan titik mendekati garis diagonalnya jadi data normal. berikut:

Penyajian one-sample kolmogorov smirnov

Tabel 3. One-Sample Kolmogorov-Smirnov Test One-Sample Kolmogorov-Smirnov Test

Unstandardized

Residual

\begin{tabular}{llr}
\hline $\mathrm{N}$ & & 135 \\
\hline Normal Parameters & & \\
& Mean & .0000000 \\
\cline { 2 - 3 } & Std. Deviation & 1.49856954 \\
Most Extreme & Absolute & .052 \\
\cline { 2 - 3 } Differences & Positive & .046 \\
\cline { 2 - 3 } & Negative & -.052 \\
\hline Test Statistic & & .052 \\
\hline Asymp. Sig. (2-tailed) & & $.200^{\mathrm{c}, \mathrm{d}}$ \\
\hline
\end{tabular}

a. Test distribution is Normal.

b. Calculated from data.

c. Lilliefors Significance Correction.

d. This is a lower bound of the true significance.

Statistik normalitasnya terlihat sig. 0,200 berada di atas 0,05 sehingga datanya normal.

\section{Uji Multikolinearitas}

Multikolinearitas ketentuan VIF $<10$ dan tolerance $>0,1$ disajikan :

Tabel 4. Hasil Uji Multikolinieritas

\begin{tabular}{ll|l|l}
\multirow{2}{*}{ Model } & & \multicolumn{2}{|c}{$\begin{array}{c}\text { Collinearity Statistics } \\
\text { Tolerance }\end{array}$} \\
\hline 1 & & & VIF \\
\cline { 2 - 4 } & (Constant) & .501 & 1.997 \\
\cline { 2 - 4 } & DPK & .497 & 2.012 \\
\cline { 2 - 4 } & CAR & .965 & 1.036 \\
\cline { 2 - 4 } & NPL & .984 & 1.017 \\
\cline { 2 - 4 } & BIRATE & & \\
\hline
\end{tabular}

Keempat variabel yang diteliti memenuhi kriteria VIF dan tolerance sehingga tidak terdapat multikolineritas.

\section{Uji Autokorelasi}

Autokorelasi dengan ketentuan $\mathrm{du}<\mathrm{dw}<4$-du.

Tabel 5. Hasil Uji Autokorelasi

\section{Model Summary ${ }^{b}$}

\begin{tabular}{lr|r|r|r|r} 
Model & R & R Square & Adjusted R Square & Std. Error of the Estimate & Durbin-Watson \\
\hline 1 & $.334^{\mathrm{a}}$ & .111 & .084 & 1.52145 & 2.190 \\
\hline
\end{tabular}

a. Predictors: (Constant), BIRATE, NPL, DPK, CAR

b. Dependent Variable: PenyaluranKredit 
Venna Melinda, Velicia, Kenji Lau dan Rafida Khairani, Pengaruh Dana Pihak Ketiga, Capital Adequacy Ratio, Non Performing Loan Dan Tingkat Suku Bunga terhadap Penyaluran Kredit Bank Umum Yang Terdaftar di Bursa Efek Indonesia

$\mathrm{Dw}=2,190, \mathrm{~N}=135, \mathrm{du}=1,7802, \mathrm{du}<\mathrm{dw}<4-\mathrm{du}$, $1,7802<2,190<4-1,7802$ hingga $1,7802<2,190<2,2198$ data tidak ada autokorelasi.

\section{Uji Heteroskedastisitas}

Uji heteroskedastisitas menggunakan metode grafik dan statistik. Grafik Scatterplot yang memenuhi ketentuan titik tersebar secara acak dan tidak berpola menunjukkan tidak ada heterokedatisitas.

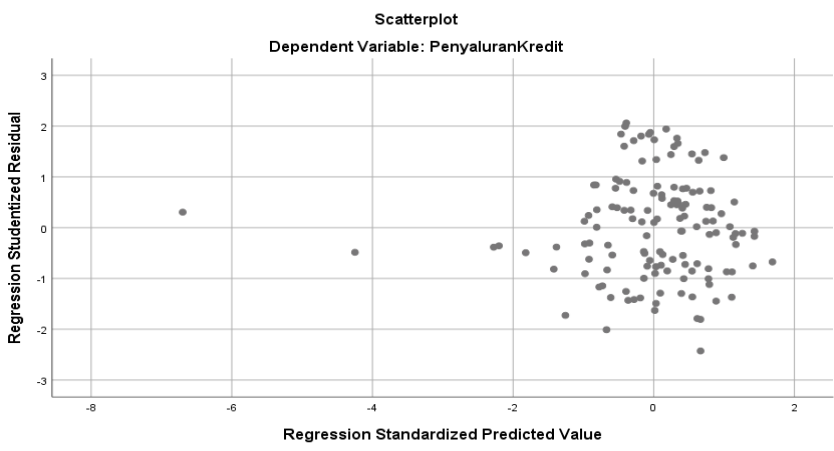

Gambar 3. Scatterplot

Grafik Scatterplot yang memenuhi ketentuan menyebar secara acak dan tidak berpola menunjukkan tidak ada heterokedatisitas.

Uji Spearman Rho dilakukan akibat glejser dan park mengalami heterokedastistik.

Tabel 6. Hasil Uji Spearman Rho

\section{Correlations}

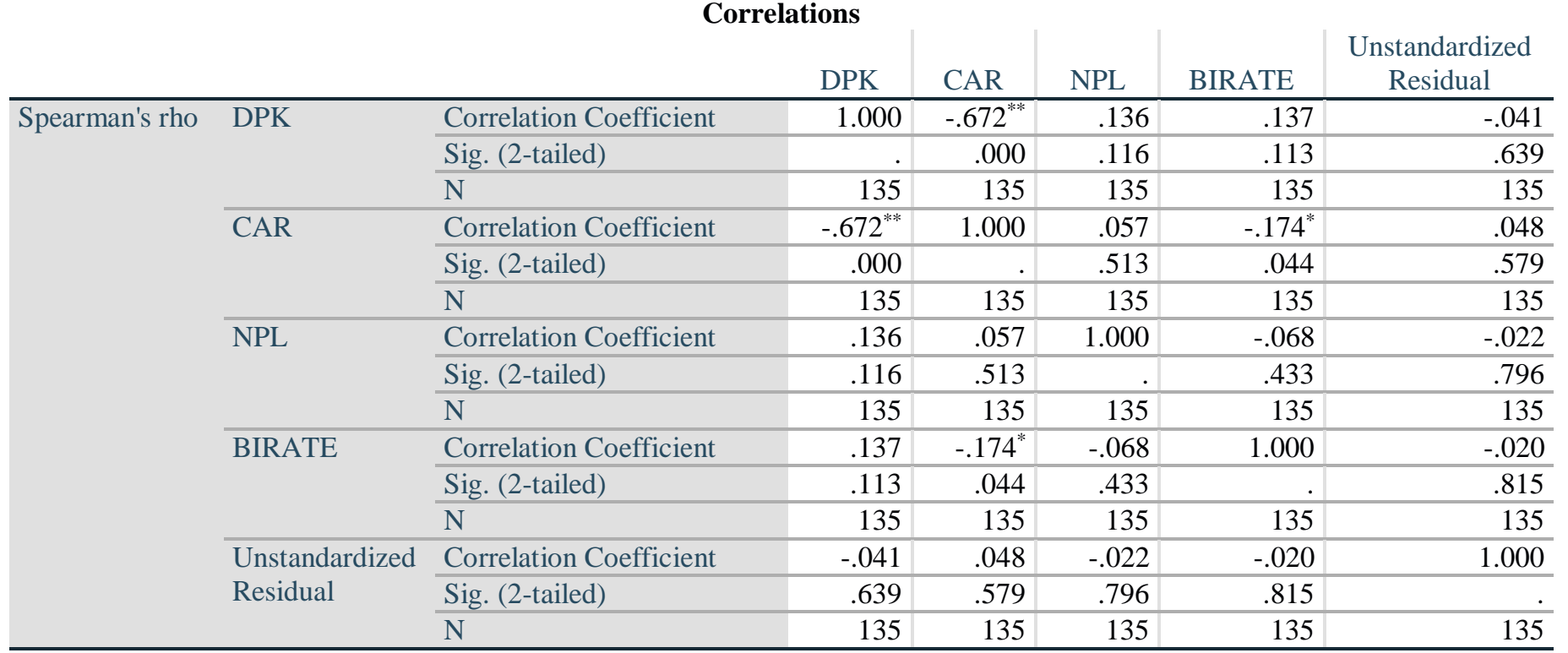

**. Correlation is significant at the 0.01 level (2-tailed).

*. Correlation is significant at the 0.05 level (2-tailed).

Statistik Spearman Rho terlihat sig untuk seluruh variabel penelitian ini berada diatas 0,05 maka tidak ada heterokedastisitas.

\section{Hasil Analisis Data}

\section{Analisis Regresi Linier Berganda}

Analisis ini dipergunakan dalam menganalisis naik turunnya variabel bebas dengan variabel terikatnya. Hasilnya terlihat dari tabel 7 :

Tabel 7. Hasil Analisis Regresi Linier Berganda Coefficients $^{\mathbf{a}}$

\begin{tabular}{|c|c|c|c|c|c|c|}
\hline \multirow{2}{*}{\multicolumn{2}{|c|}{ Model }} & \multicolumn{2}{|c|}{ Unstandardized Coefficients } & \multirow{2}{*}{$\begin{array}{c}\text { Standardized Coefficients } \\
\text { Beta } \\
\end{array}$} & \multirow[b]{2}{*}{$\mathrm{t}$} & \multirow[b]{2}{*}{ Sig. } \\
\hline & & $\mathrm{B}$ & Std. Error & & & \\
\hline \multirow[t]{5}{*}{1} & (Constant) & 31.028 & 3.171 & & 9.784 & .000 \\
\hline & DPK & .024 & .033 & .085 & .731 & .466 \\
\hline & CAR & -.062 & .028 & -.261 & -2.222 & .028 \\
\hline & NPL & -.075 & .123 & -.052 & -.612 & .542 \\
\hline & BIRATE & -.001 & .000 & -.088 & -1.061 & .291 \\
\hline
\end{tabular}

a. Dependent Variable: PenyaluranKredit 
Venna Melinda, Velicia, Kenji Lau dan Rafida Khairani, Pengaruh Dana Pihak Ketiga, Capital Adequacy Ratio, Non Performing Loan Dan Tingkat Suku Bunga terhadap Penyaluran Kredit Bank Umum Yang Terdaftar di Bursa Efek Indonesia

Penyaluran Kredit $=31,028+0,024$ DPK $-0,062$ CAR - 0,075 NPL - 0,001 BI Rate

1. Konstanta 31,028 berarti Dana Pihak Ketiga, Capital Adequacy Ratio, Non Performing Loan dan Tingkat Suku Bunga dianggap nol dengan Penyaluran Kredit 31,028.

2. Dana Pihak Ketiga 0,024 berarti meningkatnya Dana Pihak Ketiga satu rupiah maka Penyaluran Kredit meningkat 0,027.

3. Capital Adequacy Ratio $-0,062$ berarti meningkatnya Capital Adequacy Ratio satu persen maka Penyaluran Kredit menurun 0,062.
4. Non Performing Loan $-0,075$ berarti meningkatnya Non Performing Loan satu persen maka Penyaluran Kredit menurun 0,075.

5. Tingkat Suku Bunga $-0,001$ berarti meningkatnya Tingkat Suku Bunga satu persen maka Penyaluran Kredit menurun 0,001.

\section{Koefisien Determinasi $\left(\mathbf{R}^{2}\right)$}

Koefisien determinasi guna mengukur berapa besar variabel bebas bisa menerangkan variabel terikatnya.

Tabel 8. Koefisien Determinasi

\section{Model Summary ${ }^{b}$}

\begin{tabular}{llrrrrr} 
Model & $\mathrm{R}$ & & R Square & Adjusted R Square & Std. Error of the Estimate \\
\hline 1 & $.334^{\mathrm{a}}$ & & .111 & .084 & 1.52145 \\
\hline
\end{tabular}

a. Predictors: (Constant), BIRATE, NPL, DPK, CAR

b. Dependent Variable: PenyaluranKredit

Adjusted $R$ Squarenya 0,084 dengan pengaruh $8,4 \%$ terhadap penyaluran kredit dan sisanya 91,6\% dipengaruhi variabel lainnya.

\section{Pengujian Hipotesis Secara Simultan (Uji Statistik F)}

Pengujiannya $\mathrm{F}$ dilakukan variabel independent secara bersama dengan variabel dependent.

Tabel 9. Hasil Uji Statistik F

\begin{tabular}{|c|c|c|c|c|c|c|}
\hline \multicolumn{7}{|c|}{ ANOVA $^{\mathrm{a}}$} \\
\hline & & Sum of Squares & df & Mean Square & $\mathrm{F}$ & Sig. \\
\hline \multirow[t]{3}{*}{1} & Regression & 37.688 & 4 & 9.422 & 4.070 & $.004^{b}$ \\
\hline & Residual & 300.925 & 130 & 2.315 & & \\
\hline & Total & 338.613 & 134 & & & \\
\hline
\end{tabular}

a. Dependent Variable: PenyaluranKredit

b. Predictors: (Constant), BIRATE, NPL, DPK, CAR

$F_{\text {hitung }}=4,070$, sig $=0,004$ dan $F_{\text {tabel }}(135-5=130)$ $=2,28$. $F_{\text {hitung }}>F_{\text {tabel }}$ yaitu 4,070>2,28 terlihat $\mathrm{H}_{0}$ ditolak, $\mathrm{H}_{\mathrm{a}}$ diterima ditunjukkan Dana Pihak Ketiga, Capital Adequacy Ratio, Non Performing Loan dan Tingkat Suku Bunga secara simultan mempunyai pengaruh pada Penyaluran Kredit Bank Umum yang Terdaftar di Bursa Efek Indonesia.

\section{Pengujian Hipotesis Secara Parsial (Uji Statistik t)}

Uji t secara satu persatu variabel Independent terhadap variabel dependentnya.

Tabel 10. Hasil Uji Statistik t

Coefficients $^{\mathrm{a}}$

\begin{tabular}{|c|c|c|c|c|c|c|}
\hline \multirow{2}{*}{\multicolumn{2}{|c|}{ Model }} & \multicolumn{2}{|c|}{ Unstandardized Coefficients } & \multirow{2}{*}{$\begin{array}{c}\text { Standardized Coefficients } \\
\text { Beta }\end{array}$} & \multirow[b]{2}{*}{$\mathrm{t}$} & \multirow[b]{2}{*}{ Sig. } \\
\hline & & $\mathrm{B}$ & Std. Error & & & \\
\hline 1 & (Constant) & 31.028 & 3.171 & & 9.784 & .000 \\
\hline & DPK & .024 & .033 & .085 & .731 & .466 \\
\hline & CAR & -.062 & .028 & -.261 & -2.222 & .028 \\
\hline & NPL & -.075 & .123 & -.052 & -.612 & .542 \\
\hline & BIRATE & -.001 & .000 & -.088 & -1.061 & .291 \\
\hline
\end{tabular}

a. Dependent Variable: PenyaluranKredit

1. Dana Pihak Ketiga $t_{\text {hitung }}=0,731$, sig $=0,466, \mathrm{t}_{\text {tabel }}$ $(135-4=131)=1,978, t_{\text {hitung }}<t_{\text {tabel, }}, 0,731<1,978 \mathrm{H}_{0}$ ditolak, $\mathrm{H}_{\mathrm{a}}$ diterima ditunjukkan Dana Pihak Ketiga, secara parsial tidak berpengaruh terhadap
Penyaluran Kredit Bank Umum yang Terdaftar di Bursa Efek Indonesia.

2. Capital Adequacy Ratio $\mathrm{t}_{\text {hitung }}=-2,222$, $\mathrm{sig}=0,028$, $\mathrm{t}_{\text {tabel }}(135-4=131)=1,978-\mathrm{t}_{\text {hitung }}<-\mathrm{t}_{\text {tabel, }}-2,222<-$ $1,978 \mathrm{H}_{0}$ diterima, $\mathrm{H}_{\mathrm{a}}$ ditolak ditunjukkan Capital 
Venna Melinda, Velicia, Kenji Lau dan Rafida Khairani, Pengaruh Dana Pihak Ketiga, Capital Adequacy Ratio, Non Performing Loan Dan Tingkat Suku Bunga terhadap Penyaluran Kredit Bank Umum Yang Terdaftar di Bursa Efek Indonesia

Adequacy Ratio secara parsial berpengaruh terhadap Penyaluran Kredit Bank Umum yang Terdaftar di Bursa Efek Indonesia.

3. Non Performing Loan $\mathrm{t}_{\text {hitung }}=-0,612$, sig $=0,542$, $\mathrm{t}_{\text {tabel }}(135-4=131)=1,978,-\mathrm{t}_{\text {hitung }}>-\mathrm{t}_{\text {tabel, }},-0,612>-$ $1,978 \mathrm{H}_{0}$ ditolak, $\mathrm{H}_{\mathrm{a}}$ diterima ditunjukkan Non Performing Loan secara parsial tidak berpengaruh terhadap Penyaluran Kredit Bank Umum yang Terdaftar di Bursa Efek Indonesia.

4. Tingkat Suku bunga $t_{\text {hitung }}=-1,061$, sig $=0,291$, $t_{\text {tabel }}$ $(135-4=131)=1,978,-t_{\text {hitung }}>-t_{\text {tabel, }}-1,061>-1,978$ $\mathrm{H}_{0}$ diterima, $\mathrm{H}_{\mathrm{a}}$ ditolak ditunjukkan Tingkat Suku Bunga secara parsial tidak berpengaruh terhadap Penyaluran Kredit Bank Umum yang Terdaftar di Bursa Efek Indonesia.

\section{Pembahasan \\ Pengaruh Dana Pihak Ketiga Terhadap Penyaluran Kredit}

Hasil penelitian memperlihatkan Dana Pihak Ketiga, secara parsial tidak ada pengaruh pada Penyaluran Kredit Bank Umum yang tercantum di BEI. Ini dikarenakan adanya penghimpunan dana pihak ketiga yang sumbernya dari nasabah kurang produktif dikelolanya mengakibatkan penyaluran kredit menurun. Ketidakkonsisten dengan (Adnan, Ridwan dan Fildzah 2016), dana pihak ketiga yang didapat bank dari dana masyarakat yang simpan dibank dalam bentuk deposito, tabungan, dan giro. Oleh bank, dana masyarakat ini disalurkan kembali kepada masyarakat yang membutuhkan dana dalam bentuk kredit. Hasil ini tidak sama dengan Sari dan Abundanti (2016), menyatakan DPK berpengaruh positif signifikan secara parsial pada penyaluran kredit.

\section{Pengaruh Capital Adequacy Ratio Terhadap Penyaluran Kredit}

Hasil penelitian memperlihatkan Capital Adequacy Ratio secara parsial terdapat pengaruh pada Penyaluran Kredit Bank Umum yang tercantum di BEI. Ini disebabkan perbankan belum mampu mengelola permodalannya dengan baik sehingga nasabah harus membayar cicilannya yang besar. Kekonsisten dengan Putri dan Akmalia (2016) Apabila capital adequacy ratio suatu bank mengalami kekurangan dalam memenuhi modalnya maka hal itu akan dapat menghambat bank dalam menyalurkan kredit kepada masyarakat. Semakin tinggi nilai capital adequacy ratio maka bank dapat menyalurkan kreditnya. Hasil ini serupa dengan Komaria dan Diansyah (2019) menyatakan, CAR berpengaruh negatif dan tidak signifikan pada penyaluran kredit.

\section{Pengaruh Non Performing Loan Terhadap Penyaluran Kredit \\ Hasil penelitian memperlihatkan Non Performing Loan secara parsial tidak ada pengaruh pada}

Penyaluran Kredit Bank Umum yang tercantum di BEI. Hal ini disebabkan tingginya penyaluran kredit kemudian timbul kredit macet tinggi tidak berdampak apapun. Ketidakkonsistenan (Pratiwi dan Hindasah, 2014) Semakin besarnya kredit macet maka semakin meningkat pula nilai NPL bank dan kredit yang disalurkan semakin sedikit karena Bank tidak mempunyai dana untuk menyalurkannya kembali akibat kredit macet dan Bank juga enggan menyalurkan kreditnya karena mempunyai resiko tinggi terhadap hutang tak tertagih.

\section{Pengaruh Tingkat Suku Bunga Terhadap Penyaluran Kredit}

Hasil penelitian memperlihatkan Tingkat Suku Bunga tidak ada pengaruh secara parsial pada Penyaluran Kredit Bank Umum yang tercantum di BEI. Ini dikarenakan terjadinya fluktuasi yang tidak terlalu tinggi pada suku bunga serta tidak bisa mengimbangi kenaikan penyaluran kredit. Ketidakkonsisten (Sari dan Abundanti, 2016) kegiatan dalam manajemen perbankan dalam meminimalkan risiko kredit macet ialah mencari alternatif investasi yang lebih baik yaitu salah satunya melakukan penempatan dana pada SBI yang memiliki tingkat risiko paling rendah. Oleh karena itu, jika jumlah dana yang ditempatkan pada SBI meningkat maka penyaluran kredit perbankan dapat berkurang. Hasil penelitian ini sejalan dengan Haryanto dan Widyarti (2017) menyebutkan BI Rate tidak ada pengaruh negative signifikan pada penyaluran kredit.

\section{SIMPULAN}

Dari hasil penelitiannya disimpulkan berikut ini :

1. Dana Pihak Ketiga, Non Performing Loan dan Tingkat Suku bunga secara parsial tidak mempunyai pengaruh pada Penyaluran Kredit Bank Umum yang Terdaftar di BEI. Capital Adequacy Ratio pengaruh secara parsial pada penyaluran kredit Bank Umum yang tercantum di BEI.

2. Dana Pihak Ketiga, Capital Adequacy Ratio, Non Performing Loan dan Tingkat Suku Bunga mempunyai pengaruh secara stimulant pada Penyaluran Kredit Bank Umum yang Terdaftar di Bursa Efek Indonesia.

3. Penyaluran Kredit $=31,028+0,024$ DPK $-0,062$ CAR - 0,075 NPL - 0,001 BI Rate

4. Dana Pihak Ketiga, Tingkat Suku Bunga, Non Performing Loan, serta Capital Adequacy Ratio mempunyai pengaruh pada Penyaluran Kredit Bank Umum yang tercantum di BEI dimana koefisien determinasi sebesar 8,4\% terhadap penyaluran kredit dan sisanya 91,6\% dipengaruhi variabel lainnya. 
Venna Melinda, Velicia, Kenji Lau dan Rafida Khairani, Pengaruh Dana Pihak Ketiga, Capital Adequacy Ratio, Non Performing Loan Dan Tingkat Suku Bunga terhadap Penyaluran Kredit Bank Umum Yang Terdaftar di Bursa Efek Indonesia

\section{DAFTAR PUSTAKA}

Adnan, R dan Fildzah. 2016. Pengaruh Capital Adequacy Ratio, Dana Pihak Ketiga, Loan To Deposit Ratio, Dan Ukuran Bank Terhadap Penyaluran Kredit Pada Perusahaan Perbankan yang Terdaftar Di BEI Tahun 2011-2015. Jurnal Dinamika Akuntansi dan Bisnis Vol. 3(2), 2016, pp 49-64. Universitas Syiah Kuala.

Baskoro, R dan Moeliono, N. 2014. Pengaruh Suku Bunga Kredit, Dana Pihak Ketiga Terhadap Jumlah Kredit Yang Diberikan (Studi Pada PT. Bank CIMB Niaga, Tbk Periode 2008 - 2013). EProceeding of Management: Vol.1, No.3. ISSN: 2355-9357. Universitas Telkom, Bandung, Indonesia.

Darmawi, H. 2014. Manajemen Perbankan. Cetakan Ketiga. Jakarta : Bumi Aksara.

Haryanto, S dan Widyarti, E. 2017. Analisis Pengaruh CAR, BI Rate, BOPO, NPL, Dan NIM Terhadap Penyaluran Kredit Bank Umum Go Public Periode Tahun 2012-2016. Diponegoro Journal Of Management. Vol. 6, No. 4, Hal. 111.ISSN:2337-3792. Universitas Diponegoro.

Komaria dan Diansyah. 2019. Pengaruh Kinerja Keuangan Bank Terhadap Penyaluran Kredit Pada Bank Umum Konvensional Yang Terdaftar Di Bursa Efek Indonesia. Jurnal Transaksi Vol. 11, No. 1. ISSN 1979-990X. Universitas 17 Agustus 1945 Jakarta.

Latumaerissa, J. 2014. Manajemen Bank Umum. Jakarta : Mitra Wacana Media.

Pratiwi, S dan Hindasah, L. 2014. Pengaruh Net Interest Margin, Non Performing Loan, Ratio, Return on Asset, Dana Pihak Ketiga, Capital Adequacy Terhadap Penyaluran Kredit Bank Umum di Indonesia. Jurnal Manajemen dan Bisnis.Vol. 5 No. 2. Universitas Muhammadiyah Yogyakarta.

Putri dan Akmalia. 2016. Pengaruh LDR, ROA, NPL, CAR Terhadap Penyaluran Kreditpada Perbankan(Studi Pada Perusahaan Perbankan yang Listed di Bursa Efek Indonesia Periode 2011-2015. Balance Vol. XIII No. 2. Jurnal Balance. Universitas Muhammadiyah Yogyakarta.

Sari, N dan Abundanti, N. 2016. Pengaruh ROA, Suku Bunga SBI, DPK, Inflasi Terhadap Penyaluran Kredit Pada Bank Umum. E-Jurnal Manajemen Unud, Vol. 5, No. 11. ISSN: 23028912. Universitas Udayana, Bali, Indonesia.

Undang-Undang yang tercantum pada pasal 1 ayat (11) UU No.10/1998 